\title{
TOWARDS SMART \& RESILIENT URBAN SETTLEMENTS IN ASIA \& THE PACIFIC A PRO - POOR PERSPECTIVE
}

\author{
Natalja Wehmer \\ SUDS-EDD, ESCAP \\ e-mail: naschinats@yahoo.co.uk
}

\begin{abstract}
Cities and tows are places with the highest population numbers and densities on the planet. They have been the centres of conglomeration, politic, culture, innovation and connectivity within the globalized world. Globally, cities consume more water, food, vast array of raw materials and consume up to 67\% of all energy and contribute $71 \%$ of all greenhouse gas emissions. They also exhibit the contrast of poverty and wealth in close physical proximity, with slums located right next to the shining high-rises and gated elite communities. This continuous urbanization mainly swells the numbers of low-income households leading to what some experts have termed by "urbanization of poverty". However, Cities and towns are also entities whose functioning mostly depends on higher order, interrelated systems. The dynamic nature of urban environments and bad inter-relationships between infrastructure, institutions and ecosystems can lead to cascading failures or "complex disasters". This characteristic makes the urban areas different from surrounding countryside especially in vulnerabilities. The resilience here is defined as the ability to withstand, recover from and reorganize in response to crises to improve by strengthening "resilience characteristic" such as robustness, redundancy and resourcefulness and "resilience performance" such as risk reduction/ preparation, response and recovery of various population groups and urban subsystems.
\end{abstract}

Keywords: cities and towns, centre, poverty, complex disaster, resilience

\begin{abstract}
ABSTRAK
Kota merupakan tempat dengan jumlah populasi dan kepadatan tertinggi di dunia. Merupakan pusat konglomerasi, politik, budaya, inovasi dan konektivitas dalam dunia global. Secara umum, kota mengkonsumsi lebih banyak air, makanan, bahan mentah dan energy sampai dengan 67\% dari total keseluruhan dan menghasilkan 71\% dari pengeluaran gas rumah kaca. Mereka menunjukkan kontrasnya kemiskinan dan kekayaan secara fisik melalui letak permukiman kumuh berdekatan
\end{abstract}


dengan bangunan tinggi dan komunitas elit yang memiliki pagar. Proses urbanisasi yang terdiri dari permukiman berpendapatan rendah ini terus-menerus meningkat menjadi apa yang para ahli sebut sebagai "urbanisasi kemiskinan”. Bagaimanapun juga, kota merupakan perwujudan dari sesuatu yang sangat tergantung berdasarkan urutan tertinggi, sistem yang saling terhubung. Keadaan lingkungan kota yang dinamis dan buruknya keterhubungan antara infrastruktur, institusi dan ekosistem dapat membawa kepada kegagalan atau "bencana kompleks". Karakteristik inilah yang membuat daerah perkotaan berbeda dari pedesaan sekitar terutama mengenai pihak pihak yang rawan terhadap serangan. Ketahanan terhadap serangan disini didefinisikan sebagai kemampuan untuk bertahan, pulih dan mengorganisasi ulang sebagai respons terhadap krisis untuk lebih maju dengan memperkuat "karakteristik ketahanan" seperti kekokohan, kemubaziran dan kecerdikan serta "performa ketahanan" seperti pengurangan/ persiapan terhadap resiko, respons dan pulihnya komunitas dan subsistem kota.

Kata kunci: kota, pusat, kemiskinan, bencana kompleks, ketahanan

\section{INTRODUCTION}

Cities and towns are the locations with the highest population numbers and densities on the planet. They have the biggest conglomerations of physical and economic assets, and they are the centers of political power, cultural influence, innovation and connectivity within our globalized world. Cities and towns also cause dramatic land use changes (in the cities and their hinterlands) and pose the most intense demand on natural resources - to cover populations' and urban systems' needs of water, food, energy and a vast array of raw materials and intermediary products. Using these resources, cities cause most of the air, water and soil pollution, as well as waste (exemplified by growing dumpsites). Globally, cities use up 67\% of all energy and contribute to $71 \%$ of all greenhouse gas emissions.

Cities and towns also exhibit the starkest contrasts of poverty and wealth in close physical proximity - with informal and under-serviced slums located right next to shining high-rises and gated communities of the elites. While inequalities are rising, continuous urbanization mainly swells the numbers of low-income households, leading to what some experts have termed an "urbanization of poverty".

Cities and towns are also entities whose functioning most depends on higher order, interrelated systems - such as centralized infrastructure and services, a monetized, trade-dependent economy, or a sectoral, bureaucratic mode of governance, among others. The dynamic nature of urban environments and the inter-relationships between infrastructure, institutions and ecosystems can lead to cascading failures (Jo da Silva, 2012) or "complex disasters", as exemplified by the Japanese earthquake, tsunami and nuclear accident of 2011. Vulnerabilities and crises can originate in any 
one urban sub-system - be it economic, environmental, governance, infrastructure or socio-cultural - and have compounding repercussions on others.

The above characteristics not only markedly differentiate urban areas from their surrounding countryside, they also translate into very different - i.e. distinctly urban - patterns of risks and vulnerabilities. On the other hand, economies of scale and scope can work in urban areas to find solutions to the vulnerability of people and urban systems, as can dense networks of urban infrastructure and services and a wide range of expertise and resources. Resilience, here defined as the ability to withstand, recover from, and reorganize in response to crises, can be improved by strengthening "resilience characteristics" such as robustness, redundancy and resourcefulness and "resilience performance", such as risk reduction/ preparation, response and recovery of various population groups and urban subsystems (adapted from WEF, Global Crisis Report, 2013). So while cities bring distinct challenges to disaster risk reduction and climate change adaptation, they are also well placed to deliver solutions.

\section{RESULTS AND DISCUSSION}

\section{Major Urban Development Dimensions / Drivers in Asia-Pacific}

Several exogenous and endogenous drivers are creating and exacerbating urban development patterns and trends that make urban systems and populations in Asia and the Pacific particularly vulnerable to disasters and crises. Key among them are historically unprecedented urbanization (and urban economic growth), the given geo-climatic conditions of where many cities of Asia-Pacific are located, urban poverty, and urban governance. While each of them will be discussed in more detail in following sections, it is important to stress that these drivers interact with each other to compound urban disaster risks, as is depicted in the Figure 1.

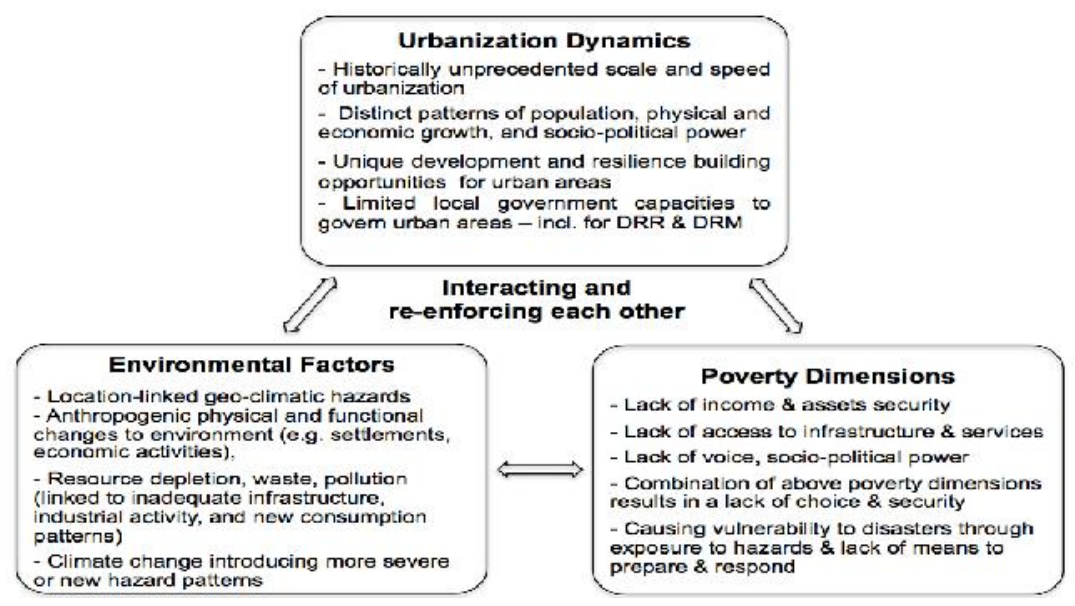

Figure 1. Inter-Relation between Urbanization, Environment and Poverty 


\section{Urbanization Dynamics}

According to 2010 estimates by UN DESA, an estimated 1.8 billion people or $43 \%$ of the total population of Asia and the Pacific live in towns and cities. While AsiaPacific is still the second least urbanized region in the world, over the last decades it has urbanized at a historically unprecedented scale and pace and while slowing down still continues to grow at $2.3 \%$ per year (ESCAP, 2011). The region is estimated to reach the $50 \%$ mark sometime around the year 2025 , becoming home to an additional 0.7 billion urbanites in only 15 years (ESCAP, 2012). This population needs adequate and resilient housing, infrastructure and services, as well as sources of income. Given that a vast portion of the already existing population still lives and works in inadequate, risky conditions, this poses tremendous challenges for city governments and other urban stakeholders. The vast population growth as well as certain urbanization patterns (such as density, ratios of young to elderly populations, urban poverty ratios, informality etc.), are contributing to making the region's cities and towns some of the most vulnerable to disaster in the world.

Urbanization drivers: Though many people equate urban growth with an influx of migrants, rural to urban migration only accounts for an estimated third of urban population growth. The other two factors are natural population growth within cities and reclassification of rural into urban area, automatically subsuming new populations. As far as migration is concerned, there are both "pull" factors, such as employment opportunities, education and health care, and better prospects of social advancement, and there are "push" factors, such as rural poverty, war and conflict and of particular importance for this report: natural disasters or slow-onset changes and environmental degradation of the countryside and in particular agricultural land.

Ecological migrants: One extreme example of the latter push factor at work is Bangladesh. The number of "ecological migrants" or "climate refugees" (mainly families who have lost land due to coastal and river erosion or who were affected by cyclones and flooding) coming to the capital Dhaka is estimated to be between 400,000 and 500,000 people per year, while according to IOM estimates, around $70 \%$ of slum dwellers in Dhaka have experienced some kind of environmental shock (New York Times, 2010; Anwer, 2012). Mainly destitute upon arrival (which is different to often better informed and prepared migration choices of other population groups), they join the poorest of the urban poor.

Cities and economic opportunities: In Asia, over the last decades, economic prosperity has been highly correlated with being urbanized. More than $70 \%$ of the region's GDP is deriving from cities (ADB 2012). The per capita GDP of Ho Chi Minh City, for example, is almost three times higher than for the country as a whole (ESCAP, 2010). Cities as locations of economic opportunities and modern amenities and leisure are so attractive that, bearing a most extreme crisis, even hazard-prone onesare unlikely to see a reduction in population growth in the next 10 to 20 years. 
Public policies aimed at slowing down the growth of cities are unlikely to succeed (Lall and Deichmann, 2010).

Poorest growing fastest: At the same time, it is least developed and low-income countries starting with low urban population rates that have experienced the highest urban population growth rates over the last decades. While highly urbanized Japan (90.5\% urban) or Republic of Korea $(82.9 \%)$ have very low urban population growth of $0.6 \%$ and $0.7 \%$ respectively, least developed countries starting out with low urban population rates, such as Lao PDR with $33.1 \%$ or Nepal with $16.7 \%$, are experiencing much higher annual urban growth rates of $4.4 \%$ and $3.6 \%$ respectively. In the short term it burdens cities in those countries least able to cope with rapid urbanization with fastest population growth. Moreover, as mentioned, much of that population growth takes place among lower income groups. Due to high demand for land, these city dwellers are largely then pushed into more and more risky and marginalized areas, compounding vulnerabilities of populations and urban systems.

Given developing countries' weak institutions and lower capacity to provide the necessary infrastructure and services, one visible expression of fast urbanization has been the proliferation of slums and informal settlements. ESCAP estimates that Asia and the Pacific now has around 571 million slum dwellers (ESCAP, 2010) making up around a third of the region's urbanites.However, in some countries and cities this percentage is much higher; for example, in Bangladesh, Cambodia, the Lao People's Democratic Republic, Mongolia and Nepal, a majority of the urban populations live in slums.

Megacities versus smaller towns: Another continuing trend is the growth of extended urban regions around large cities. These mega agglomerations can encompass a number of urbanand rural local governments and transcend metropolitan or provincial boundaries. Examples include New Delhi, Tokyo, Beijing, Manila, Bangkok, Shanghai and Jakarta. The Bangkok metropolitan area, for example, covers over $7,760 \mathrm{~km}^{2}$, with a population of over 10 million spread over the jurisdiction of the Bangkok Metropolitan Administration and five surrounding provinces. The Jakarta-Bogor-Tangerang-Bekasi region (Jabotabek) has a total population of over 21 million and a land area of over $6,400 \mathrm{~km}^{2}$.

This has required governments to rethink mechanisms and institutions of urban planning, management and governance. One issue, for example, is that these settlements are occupying rural areas that have lower planning and building standards, and more lax environmental regulations, resulting in haphazard development that closely intermingles different forms of land use industrial, residential, commercial and agricultural. Moreover, as they radiate along transport corridors, they take the form of "ribbon" or "strip" development that ignores large tracts of land further away from the main arteries (ESCAP, 2009). This results in development that is environmentally unsustainable, as it is both resource intensive and often increases pollution and disaster risk. 


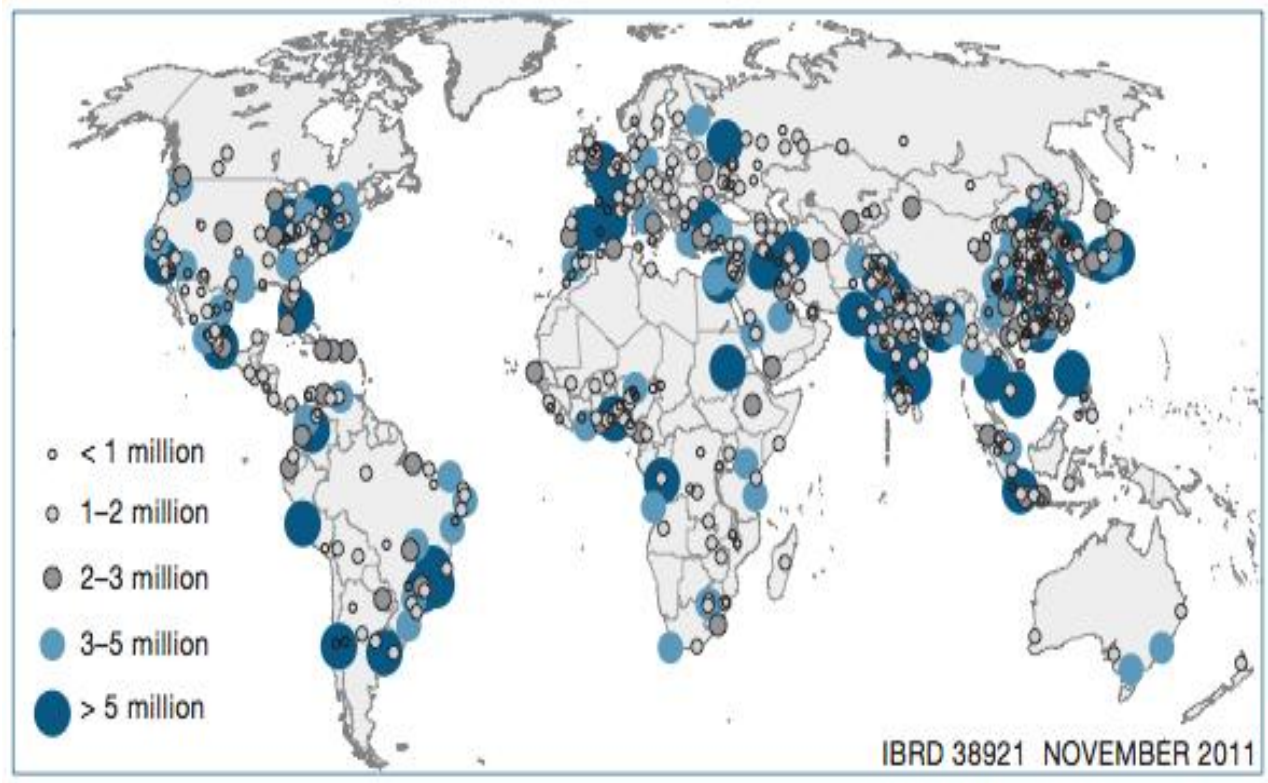

Figure 2. Urban Agglomerations with More Than 750,000 Inhabitants, 2010 Source: DESA, World Urbanization Prospects, 2009 revision

In 2010, 12 of the world's 21 mega cities (i.e. cities with more than 10 million inhabitants) were located in Asia (ESCAP, 2011). While mega cities and extended urban regions are a very visible expression of urbanization with complex governance challenges, including when it come to disasters, only around $10 \%$ of the region's urban population live in mega cities. $60 \%$ of the urban population of the region lives in cities of a million or less. Problems and challenges facing these cities and towns often attract less attention than those of mega-cities because mega-cities have much greater political capital (ESCAP, 2012).

\section{Environmental Factors}

Encompassing both the "Pacific ring of fire" and the "typhoon belt", including a multitude of low-lying islands and vast and densely populated coastal areas under threat of sea level rise, and being home to the Himalayan glaciers and many of the world's large and densely populated rivers prone to flooding, Asia and the Pacific is the most disaster-prone region in the world. Many of the exposed, as well as indirectly affected areas are urban. According to the World Bank, out of 15 large disasters with major impacts on cities worldwide between 2000 and 2010, 10 happened in Asia-Pacific (World Bank, 2012) - excluding the 2011 complex disaster of the Japan earthquake and tsunami.

As shown in Figure 3, flooding is the most common urban disaster risk in AsiaPacific. However, many cities face multiple disaster risks. 


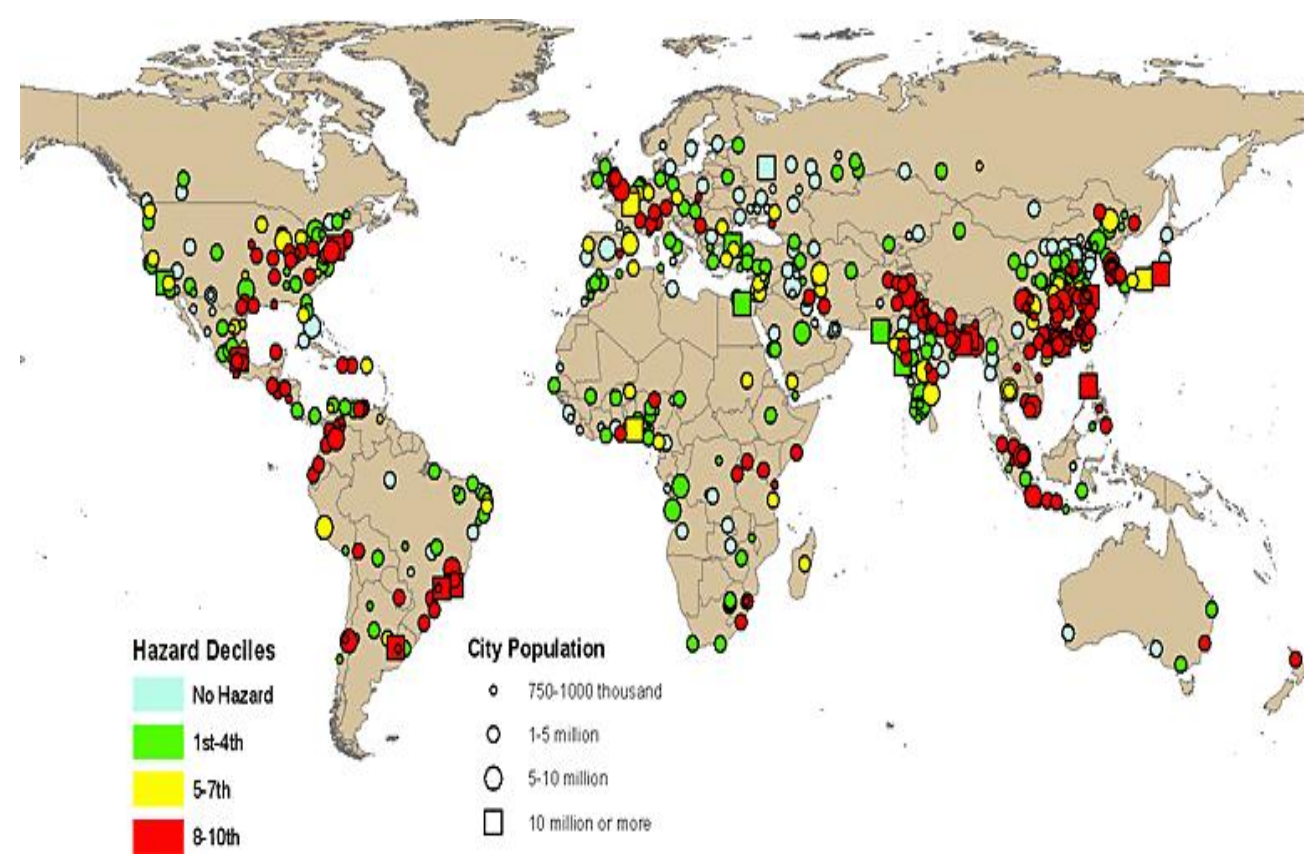

Figure 3. Urban Agglomerations by Size Class and Potential Risk of Flooding, 2011 Source: United Nations, Department of Economic and Social Affairs, Population Division: World Urbanization Prospects, the 2011 Revision. New York 2012 http://esa.un.org/unpd/wup/Maps/maps_flooding_2011.htm

Many of Asia's major cities have been established in some of the most hazardous locations possible facing combinations of geophysical, hydrological, meterological, and climatological risks (ADB, 2012). As shown in Map 3, 52\% of the urban population of Asia live in low-lying coastal areas with multiple disaster risk and slowonset stresses.

With climate change, urban disaster risk will also change and likely increase, in what can be summarized as three types of changes (Dodman \& Satterthwaite, 2008). Firstly, there will be changes in means and slow-onset impacts. Changes in mean temperature will lead to increased energy demands for heating and cooling, worsening air quality and more pronounced urban heat island effects. Changes in mean precipitation will lead to increased risk of flooding, landslides, further distress migration from rural areas and interruption of food supplies. 


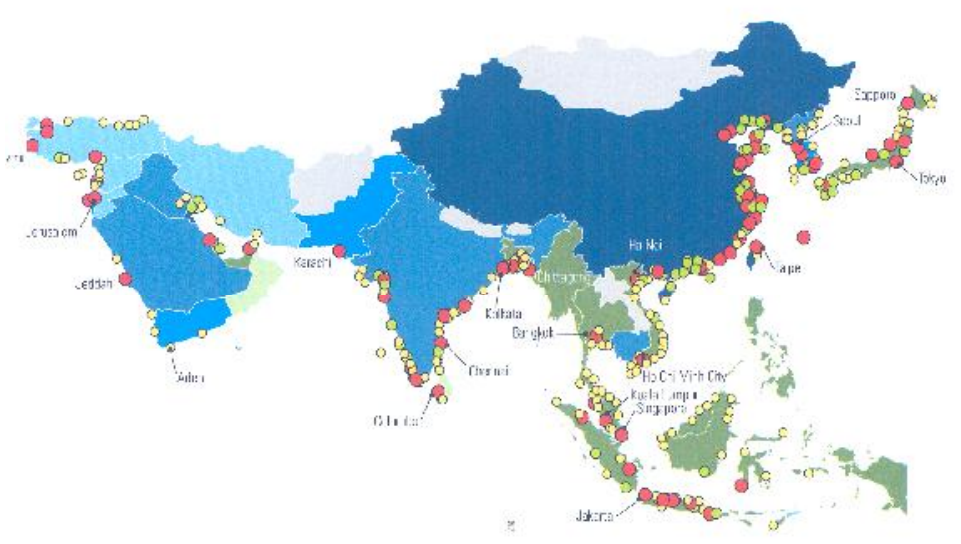

$\%$ of national urban population in urban LECZ

\begin{tabular}{|c|c|}
\hline Non LECZ & City size \\
\hline $0.0-5.0$ & Small \\
\hline $5.1-10.0$ & $\bigcirc$ Intermediate \\
\hline $10.1-15.0$ & Big \\
\hline $15.1-20.0$ & Population of cities \\
\hline $20.1-25.0$ & Small: 100 - 500 thousand \\
\hline$>25.0$ & Big: More than 1 million \\
\hline
\end{tabular}

Data source: Coastal Analysis Data Set utilizing GRUMP beta population and land area grids (CIESIN, 2005), Low elevation Coastal Zone created from SRTM elevation grid (CIESIN, 2006). GRUMP (Global Rural - Urban Mapping Project) is a project of the Center for International Earth Science Information Network (CIESIN) at the Earth Institute, Columbia University.

LECZ: Low Elevation Coastal Zones are land areas that are contiguous with the coast and ten metres or less in elevation.

All grids $1 \mathrm{~km}$ resolution.

Figure 4. Urban Settlements in Low-Lying Coastal Areas Source: UN Habitat (2009) "State of the World's Cities Report 2008/2009 :Harmonious Cities"

Sea-level rise will lead to increased coastal flooding, loss of land and reduced income from agriculture and tourism as well as salination of water sources. Secondly, there will be changes in extremes such as extreme rainfalls and winds leading to more intense and frequent flooding, risks of landslides with disruptions of 
livelihoods and city economies, damage to homes and businesses, and fatalities. Thirdly, there will be changes in exposure as disease patterns change due to extended vector habitats and stressed rural habitants migrate to cities where, like growing urban poor households, they are likely to settle on marginal, increasingly hazard-prone lands.

In addition to risks directly occurring within city boundaries, climate change will also affect urban populations and systems indirectly through events that occur outside city boundaries, such as droughts driving up food prices, reducing water sources from outside cities and triggering rural to urban migration, or floods accumulating hundreds of kilometers upstream.

Bai and Imura (2000) have provided an insightful analytical framework to describe the environmental evolution of cities as three stages, where resource use, waste and pollution occur due to different drivers causing different types of environmental risk. The first stage is the poverty stage, characterized by high rural to urban migration, low per capita income, and inability of local government to manage its urban resources, resulting in insufficient urban infrastructure and services and pushing large sections of the urban population to live in slums (see next section for more detailed discussion of urban poverty). While the associated environmental risks are mainly local, they create distinct spatial patterns of vulnerability to disasters and hamper citywide resilience.

The second stage is the early industrial development stage, where pollution intensive industry and older technologies cause air and water pollution, while environmental and labour-safety regulations are weakly enforced. Impacts here can be local and regional and can contribute to complex disasters, where one disaster trigger (e.g. heavy rain causing floods) then interacts with another (e.g. big amounts of toxic material from a flooded factory entering the water system). The third stage is that of mass production and consumption, characterized by unsustainable natural resource use, large-scale pollution and waste generation. It has local, regional and global impacts with large urban carbon footprints driving climate change that in turn negatively impacts on disaster patterns. An ideal fourth stage would be the sustainable and resilient city, which has not been achieved anywhere yet.

Historically, for Western countries and for East Asia, these three stages happened consecutively, giving governments and city populations some time to implement incremental improvements - or in other words to adapt and enhance resilience. For many cities of Asia and the Pacific however, these three stages now happen so quickly, they overlap - though often in spatially and socially disaggregated patterns with urban poor communities disproportionally suffering from risk impacts of all three stages. 


\section{Environmental evolution of cities}

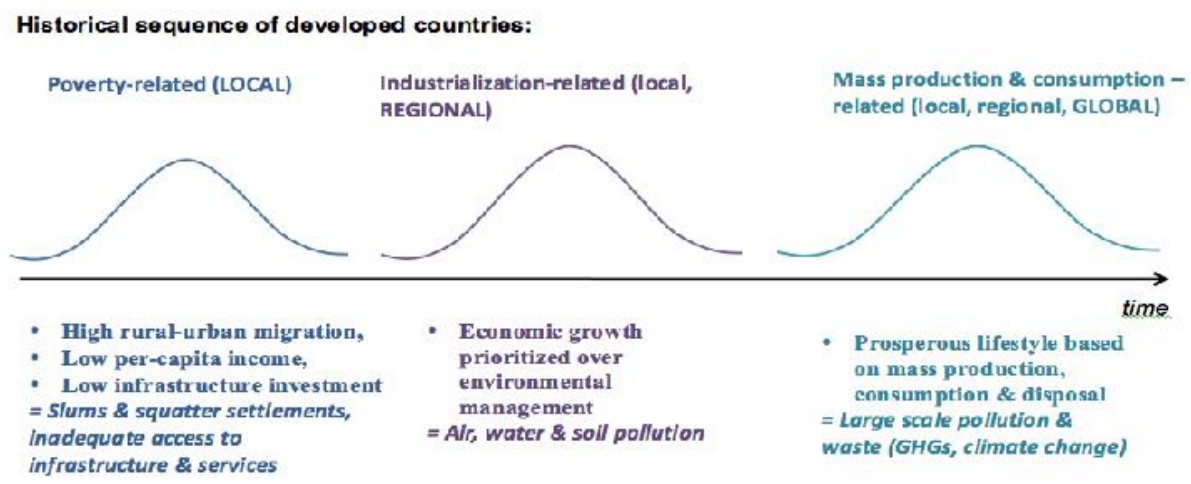

Challenge for Asia and the Pacific:

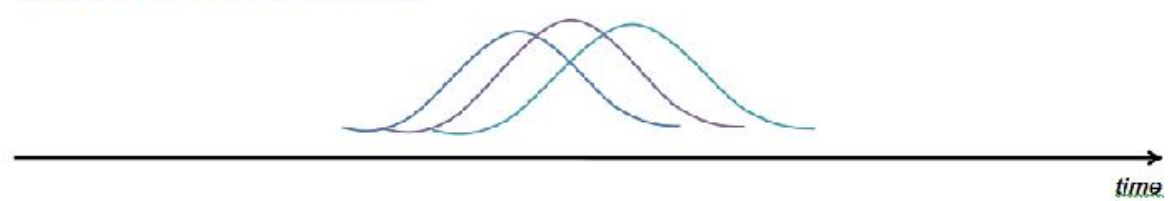

Figure 5. Environmental Evolution of Cities According to Bai \& Imura

This further underlines the unprecedented set of interlinked challenges that city governments and other urban stakeholders in Asia-Pacific face today: they have to manage the biggest and fastest increase in urban populations and spatial spread the world has ever seen, while their cities simultaneously grapple with environmental risks linked to poverty, industrialization and conspicuous consumption, in locations of particularly high geo-climatic exposure to extreme events and slow-onset changes.

\section{Poverty Dimensions}

According to the IFRC World Disaster Report (2010), Japan has more people exposed to typhoons than the Philippines. However, if a storm of the same magnitude would hit, past experience is suggesting that mortality in the Philippines would be 17 times higher than in Japan. Why is this and who are the people most likely to die? Though not the only dimension of disaster vulnerability, urban poverty is arguably the main driver for the many deaths in cities and towns of the region's developing countries. For example, during the tragic 2011 flash flood in Cagayan de Oro, Philippines, $95 \%$ of death \& damages were among informal settlers - many of whom had settled on sand banks by the river and on islands, living flimsy huts. In another example, the 2011 floods in Thailand, 2/3 of the urban poor were affected versus $1 / 3$ of the urban population as a whole. 
Poverty multi-dimensional: As already shown in Diagram 1, poverty multidimensional and the dimensions are interlinked compounding vulnerabilities and leading to the famous "poverty trap". This is important to keep in mind, as increasing resilience means tackling all these structural development issues.

Urban poverty often underestimated: In both international comparisons and national poverty lines, there is no conceptual (and often also operational) disaggregation between rural and urban poverty. While in rural areas a lot of people's daily needs can be covered self-sufficiently, through barter or are free (like perhaps water), in urban areas people have to pay for almost all goods and services. Given especially the high cost of shelter and of transportation, USD 2 per day very quickly seize being a meaningful threshold to divide the poor from the non-poor. However, the result of not defining urban poverty more realistically and recognizing the characteristics that differentiate it from rural poverty, is that urban poverty is not only not fully captured, but that in many countries it is still neglected in national policies.

Slums as physical expression of poverty: Not all slums are equal. Originally, slums refer to run-down neighbourhoods with legal housing, which often is illegally subdivided. Informal settlements are new settlement on any vacant land where residents squat in inner cities or illegally sub-divided agricultural land in the periphery. Some decades ago, households might have been able to find land in cities on which they squatted for free, but nowadays, the right to reside on land informally is controlled by informal housing markets that follow the laws of demand and supply discounting for the risks associated with informality.

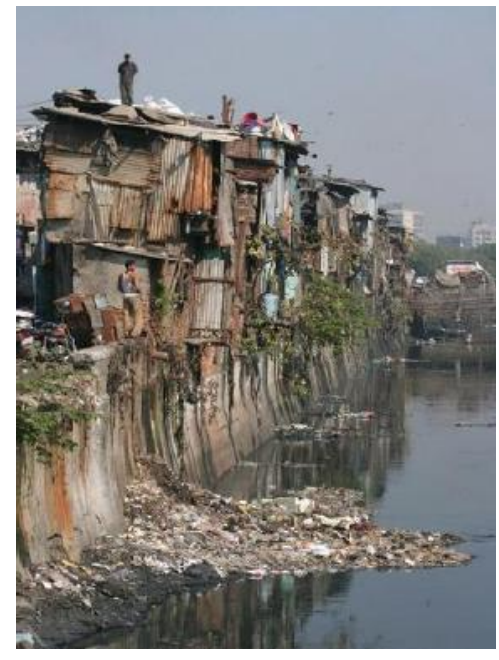

Figure 6. Slum Area Expression

If the "market" decides on land distribution, the outcome is high prices for formal housing that are not affordable for most urban poor households. Finding themselves 
"between a rock and a hard place", urban poor households carefully weigh-up very limited and tough choices on where to live and what kind of living conditions to accept. While there may be affordable, better quality and legal housing in the periphery of a city, a likely lack of income opportunities and often of infrastructure and services would necessitate commuting to the city - which in turn is very costly and time-consuming. Also, the type of income generating activities many urban poor engage in (such as street vending) may not be suitable for commuting. Living outside the city may therefore simply not be economically viable or entail further, significant impoverishment.

Extensive disasters: Another important point to note is that while the large disasters make it into news and databases, much damage and loss of life in urban poor communities is caused by small-scale disasters and culmination of everyday stress factors, such as a flashflood killing 30 people and flattening an informal settlement or a typhoon blowing away the 20 most exposed houses in a slum at the sea shore. Furthermore, the increased exposure of urban poor households and communities to everyday hazards (such as clogged drainage in the absence of solid waste management and sanitation) can quickly exacerbate situations and turn into smallscale disasters. These events, called 'extensive disasters' by Satterthwaite (2011) are not recorded in any international disaster statistic and so the extend of urban poor communities' vulnerability remains under-recorded.

Lack of understanding and marginalization in public discourse: Outsiders (including the country's elites that carry much of the responsibility for the economic and political decisions that leave the poor with this limited set of choices) often do not appreciate or care for the true cost of alternative living locations for a household that has to make do with only a few Dollars a day. Instead, the implicit accusation in a lot of mainstream public discourse is that the urban poor are free-riders not wanting to pay for land, housing and basic services - squatting on canals, illegally tapping electricity etc. Sure, gangs, crime, drugs exist in urban poor communities. However, most urban poor are working hard just to survive and even if they squat, they pay something to someone, while their per unit costs for water and energy are often higher than those of middle class households.

This negative perception will hardly change unless the poor have a voice and a space to express their views and their needs. More often then not, today decisions on where the poor live - and therefore largely also with what kind of disaster risks they live - are made for them by others, explicitly or as a by-product. Those others then do not share these risks. The dilemma for urban governance in many of the region's cities is: How can a sizable urban population group that is neglected for much of its everyday needs (which is the root cause of much of their vulnerability in the first place) be adequately prepared for extreme events?

Resettlement as knee-jerk reaction: Whether driven by a sincere wish to move people out of harm's way, or the need to free waterways along which informal settlers often reside for dredging or other flood control measures, or just using 
disaster as a pretext for evictions, many urban decision makers and the general public advocate for resettlement. However, resettlement can quickly turn into a second disaster for the urban poor if not undertaken in a participatory way that is sensitive to their needs. If possible, decision-makers and stakeholders should opt for upgrading of existing informal settlements (alongside with securing tenure), as this options is much cheaper and less disruptive to lives, social networks and livelihoods. Other good options can include re-blocking housing on the same land or nearby resettlement. One of the pioneers of implementing such pro-poor approachesat scale is the Community Organizations Development Institute (CODI) in Thailand, with its Baan Mankong Programme described in the next section.

Poverty and vulnerability: Being poor is not the same as being vulnerable, however, poverty is one main driver for vulnerability because, as noted by Dodman and Satterthwaite (2008) it results in:

- Greater exposure to hazards (e.g. through living in makeshift housing on unsafe sites)

- Lack of hazard-reducing infrastructure (e.g. drainage systems, roads allowing emergency vehicle access)

- Less adaptive capacity (e.g. the ability to move to better quality housing or less dangerous sites)

- Less state provision for assistance in the event of a disaster (indeed, state action may increase exposure to hazards by limiting access to safe sites for housing)

- Less legal and financial protection (e.g. a lack of legal tenure for housing sites, lack of assets and insurance).

This vulnerability that comes from being poor then is interlaced and compounded by other drivers of vulnerability such as age or gender or some types of marginalization related to race or religion or caste.However, while the urban poor have less adaptive capacity at individual or household level, they can to a certain extend compensate for that through collective measures - building up social capital and empowering and organizing their communities. A lot of disaster preparedness and mitigation at the household and community level does not have to be costly but has a lot to do with organizing systems for early warning, evacuation or savings. Over a longerterm horizon, well-organized communities can also achieve security of tenure and lease or own secure housing. That the urban poor do not have to be passive victims of disasters but can be active survivors and victors is illustrated, for example, by the work of the Homeless Peoples Federation of the Philippines (HPFPI-PACSII) in the Iloilo city, described in the next section.

\section{Governance}

Urban governance, in the context of smart and resilient cities, is the crucial link that at city level brings together the 'hard' and 'soft' components of disaster preparedness, response and reconstruction and that fosters robustness, redundancy and resourcefulness in populations and urban systems. 
Governance relates to how a web of institutions and actors are managed and coordinated to make and implement decisions in accordance with certain regulations and plans, and managing and relying on a set of infrastructure and services. Ideally these institutions, regulations, infrastructure and services equitably provide for an entire urban population's daily needs, are properly financed and equipped, are subject to a well-functioning quality control, and are designed to function in extreme situations (Satterthwaite, 2011). In reality, most local governments in developing countries of the Asia-Pacific region experience numerous deviations from this ideal stage with weak underfunded institutions and inadequately trained staff, and with incomplete or decaying infrastructure and services that only reach part of the urban population.How governance plays itself out in a city depends a lot on a certain country's administrative and political structure (e.g. degree of decentralization and elite capture), a city's economic power and socio-cultural rules.

Mostly though, local governments experience challenges of vertical (i.e. different hierarchies from national to neighbourhood levels) and horizontal (i.e. different sectors and issues) integration and have difficulties to govern across spatial (e.g. disasters do not respect city borders and may need cooperation between various municipalities) and temporal (timeframes of electoral cycles versus long time horizons and impact delay for many stresses and crises) dimensions.

One concept to counter-act above challenges that is discussed in mainly academic circles is adaptive governance. Several definitions and approaches exist, such as for exampleDjalante's (2012) framework that explores the concept in the context of resilience to natural hazards. He argues that adaptive governance can be a more effective approach for addressing complex environmental challenges. In his view, it exhibits four main characteristics, namely: polycentric and multilayered institutions, participation and collaboration, self-organization and networks, and learning and innovation. It represents a less rigid, uniform, prescriptive, and hierarchical approach, instead embracing more collaborative, decentralized, multilevel, and flexible decision-making that devolves control to participatory and multi-stakeholder approaches, pursuing explicitly adaptive approaches. However, adaptive governance is a theoretical framework and while certain urban DRR and DRM practices exhibit some of the listed features, none exist empirically that are conforming to all. While the advantages are clear, the challenges are also formidable:

1. Advantages

- Opportunity of pooling local and multiple sources knowledge, performing a comprehensive assessment of problems, reducing uncertainties, increasing legitimacy, sense of ownership and compliance, and triggering innovations.

- Over the medium to long term, redundancy can be structurally increased and failure is likely to be reduced.

- Pooling knowledge and resources allows everyone to focus on those interventions they are best placed to undertake and the coordination means everyone's efforts go further and complement each other.

- Participation and collaboration builds social capital, which has proven to be a 
strong driver for fast recovery (e.g. after the Kobe earthquake of 1995 in Japan) and vital to avoid conflict (e.g. inclusion of local networks after the 2003 earthquake in Bam, Iran and the 2004 Indian Ocean tsunami of 2004 in Sri Lanka ensured ethnic neutrality and social harmony).

- Flexibility in the operations of civil society organizations, including groundlevel community-based organizations and also private sector entities, can speedup deployment of resources without having to pass through long bureaucracy.

2. Challenges

- It can significantly heighten transaction costs (including in terms of time) and esp. in the beginning can decrease efficiency.

- It is also ineffective if lower government levels or other stakeholders do not have power and resources.

- It only works if different actors, agencies and government are willing to share power. Leadership experience and quality matter.

- Compliance depends on the extent to which solutions derived from collaboration bind all collaborating parties, and how group identities and allegiances are formed. Effectiveness can be reduced when membership is not representative or involvement is not meaningful. It is important to both ensure that powerful players see value added and that marginalized actors are given a voice.

- Bias and incomplete knowledge can undermine participation and lead to additional conflict or result in lowest common denominator solutions.

- Without larger institutional stability such adaptive governance platforms might not be sustainable in the long term and it can be challenging to identifying who is accountable for what within loose and informal networks.

- Technical, logistical, and financial challenges can stymie the collection of baseline environmental data. Also, governments need to see the value added in sharing data, including from monitoring and evaluation, so it needs to be clear why data are collected, who is to collect it, and who has access to it.

- The sheer complexity and scope of environmental problems that spread over large geographical areas can be overwhelming and frequently, short-term project planning and implementation does not allow for the monitoring and evaluation of long-term processes.

\section{Examples of People-Centered Holistic Approaches to Community Development in Cities of Asia and the Pacific}

In many countries of Asia and the Pacific, when outsiders be it governments or donors - have tried to improve housing and infrastructure in a city to benefit urban poor households, even with the best of intentions, their approaches and impacts were often not in sink with their stated aims and with the needs and living realities of the urban poor. For example, multi-story walk-up apartments rented out or sold through mortgages do not fit many slum dwellers' informal living and working arrangements, as many would have problems making regular payments or continuing their income generating activities from a fourth floor room (Where do 
you store your push cart? How would you run a motorcycle repair business? Where to sort and store recyclables?). Thus many housing projects intended for the poor have run into repayment difficulties, became degraded as maintenance became an issue or have led to displacement of the poor (often back to slums) they were intended for. Also, because such "supply-driven" or "cookie-cutter" approaches tend to be more costly and budgets are limited, they fail to meet need at scale.

Looking for more efficient and demand driven solutions, over the last few decades many organizations, especially within civil society be it non-governmental organizations or community-based organizations, have implemented successful approaches from the grass-roots up and many have joined together in regional networks such as the Asian Coalition for Housing Rights (ACHR) or global networks such as Slum/ Shack Dwellers International (SDI).

Most of them share similar approaches, such as addressing community development in a holistic way: it is not just about housing or about livelihoods - it is about empowerment to solve any of the many issues a community or city faces - and it is about addressing them in a sustainable way, increasing people's and systems' resilience. Another aspect is to put the urban poor communities at the centre of development - as they know their needs and abilities. Indeed, under logos such as "people are the solution", some (for example under ACHR's ACCA programme) have inverted the classical development paradigm of governments or outside donors inviting communities to 'participate' into communities inviting governments and other stakeholders to join their initiatives.

At the heart of these grass-roots approaches are often credit \& saving groups, which have nothing short of revolutionized Asia's Community organizations as they are a simple \& direct way for people to take care of immediate needs, represent an active way of building community organizations, create structures of cooperation, mutual assistance $\&$ collective action, build up power \& money, and develop people's skills to handle larger development projects. The sequence of community empowerment starts with collecting own money, growing own power through organization and capacity development, collect own information, and then reach out to governments and other stakeholders to negotiate from apposition of strength.

\section{Community Organizations Development Institute, Thailand}

CODI, a public organization under the Ministry of Social Development and Human Security, Thailand, is managing the Baan Mankong Programme, one of the most advanced examples of a country-wide slum and squatter upgrading \& resettlement programmes in Asia and the Pacific. It encourages existing slum communities to form co-ops to manage their land tenure and develop their housing collectively, in order to avoid by-outs of individual housing units from the poor and their reselling to higher income groups. The programme started in 2003 and so far has assisted over 1500 communities with over 90.000 households in 277 cities in Thailand. The key to success is that communities are involved at every step and empowered to 
make their own decisions. CODI channels government funds (infrastructure subsidies and soft housing and land loans) directly to poor communities and the communities plan and improve their housing, environment and basic services and manage budget collectively. The first step is establishing saving groups. Next, communities collaborate with local government, professionals, universities and NGOs to secure tenure, survey communities \& plan upgrading or resettlement.

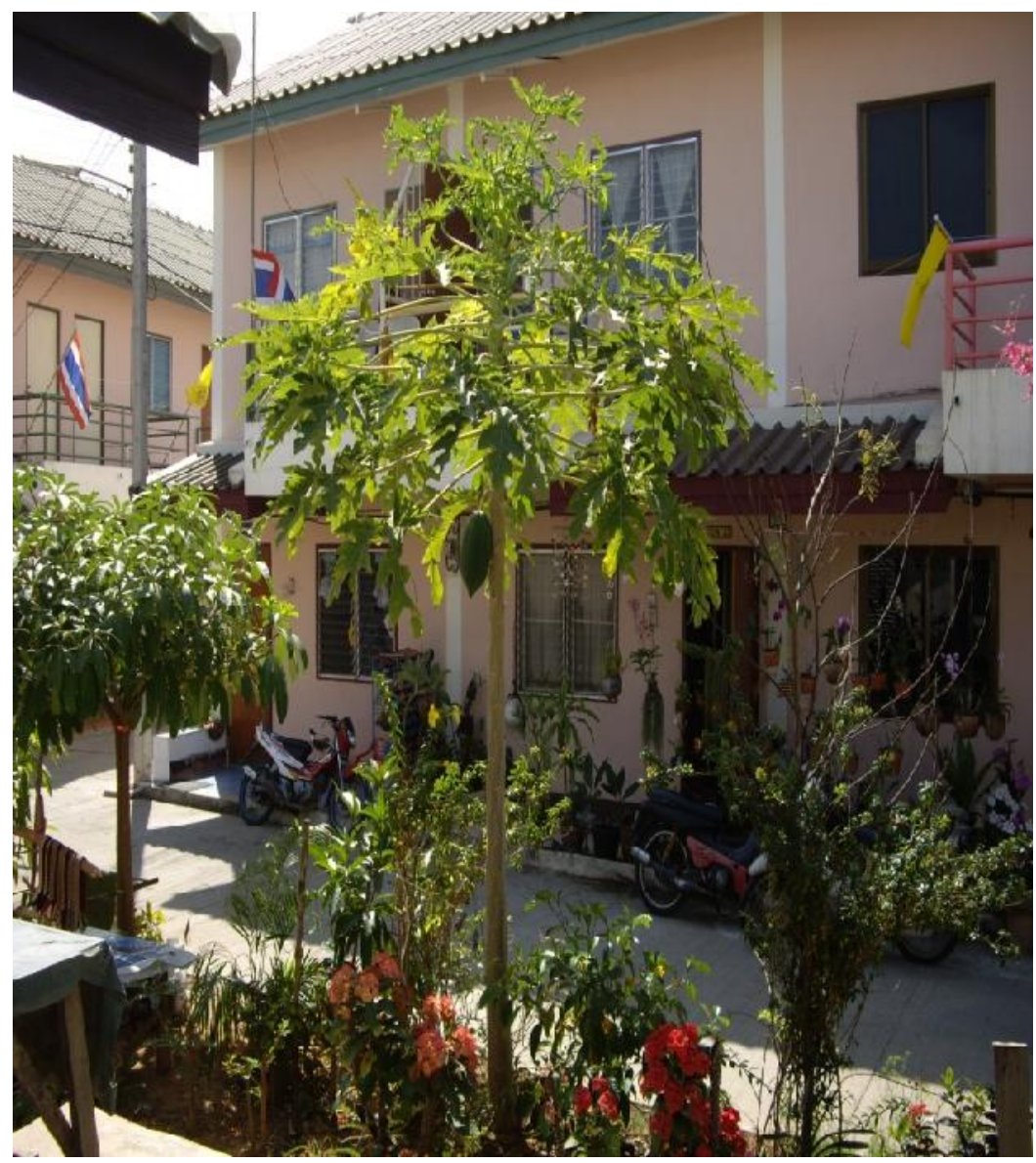

Figure 7. Baan Mankong Housing Project Example Source: field visits co-organized by CODI \& ESCAP

After that CODI provides the subsidies and loans, which each community repays collectively. Throughout, communities support and teach each other in community networks through visits, workshops, loans and inaugurations. This way, each partner in the process - from governments to professionals, to communities supports the process suing their core competencies and capacities. 


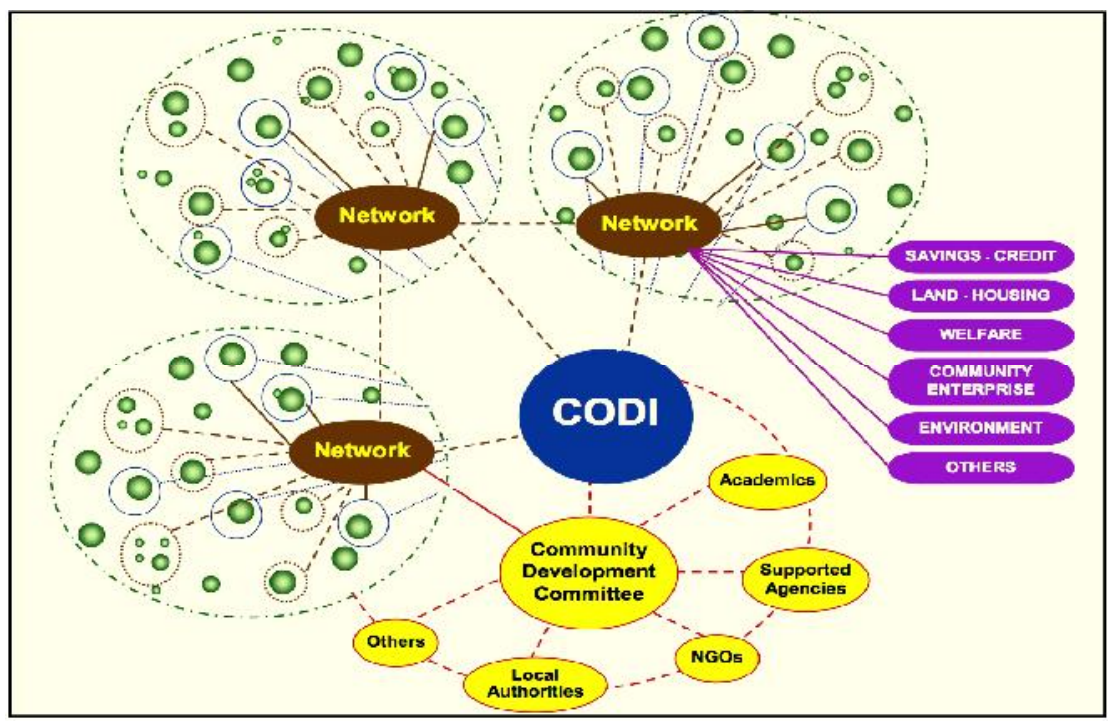

Figure 8. Baan Mankong Network Structure Source: Field visits co-organized by CODI \& ESCAP

Of course such a complex process, especially if it is undertaken city-wide is not without challenges and will take time, but the bottom line is that it reaches lowincome households in a far more efficient way than conventional low-income housing projects - and that it provides more than housing - it develops communities with a social fabric able to solve all sorts of development challenges.

\section{Iloilo City Urban Poor Network, Philippines}

In Iloilo City, in the Philippines, the local government, as part of a large-scale flood control project sought to relocate 3000 families living along rivers and canals to a resettlement site set aside by the city's land banking efforts. In the beginning, people were very reluctant to resettle, but when typhoon Frank hit in 2008, a flash flood brought death, casualties and destruction of infrastructure and mainly informal housing. As thousands of flashflood victims could not return to their previous settlements, a multi-stakeholder consortium consisting of the Iloilo City Urban Poor Network (ICUPN), the Iloilo City government, National government agencies, and other private and non-governmental organizations jointly planned and implemented an interlinked set of alternative solutions that went beyond the usual dole-out and short-term relief assistance.

ICUPN, following community consultations straight after the disaster, undertook two demand-driven post-disaster interventions: provision of housing material loans for households with partially damaged structures, and temporary shelter for some of the households that had become homeless. 
While other socialized housing providers / donors delivered over 1000 permanent one story housing units to affected families on the resettlement site for free, ICUPN offered affected communities a housing loan of between 70,000 and 150,000 pesos repayable over 15 years. Having a choice between the free housing (where layout and design were given) and taking the loan, 172 families preferred to pay and in turn be in charge of their housing design, procurement and construction through a collective, participatory process, which also entailed joining the community savings program and taking part in regular meetings and capacity building activities. They felt that if they took things into their own hands, they could develop housing that was value for money, good quality and corresponding to their needs.
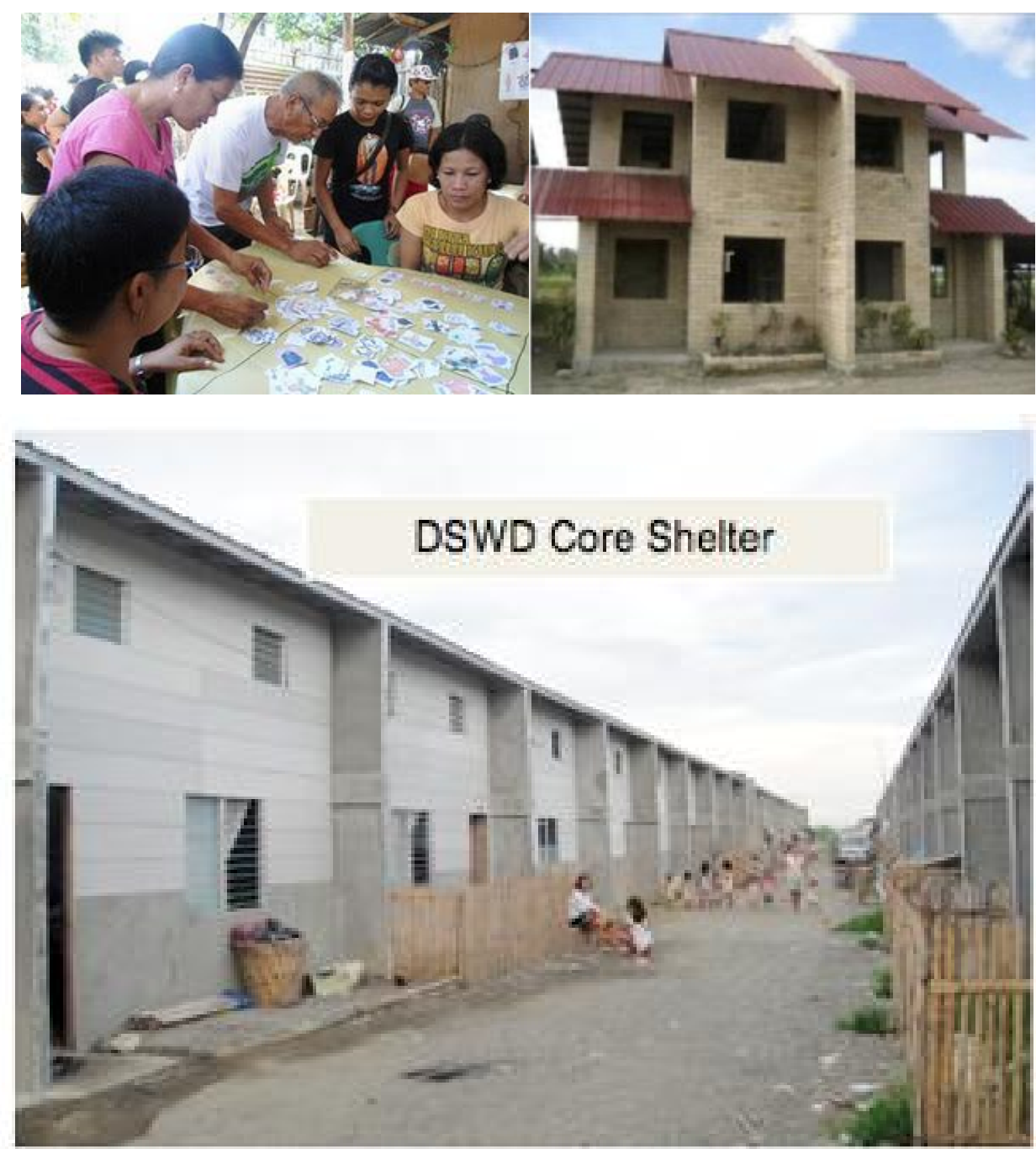

Figure 9. Participatory Planning Process, ICUPN Project Housing, Housing of Socialized Housing Provider on Resettlement Site, Iloilo, Philippines Source: HPFPI-PACSII 
This set of interlinked interventions clearly shows the benefits of all stakeholders working together, in real partnership. Together, they were able to support many of the most vulnerable in their city from immediate post-disaster response all the way through to permanent housing solutions and empowered communities. The stakeholders complemented each other's strengths to effectively deal with disasters and make their communities and city more resilient. Also, not only the communities gained. Having proven that their demand-driven approach worked, the local government invited ICUPN to join the local housing board and other committees and processes to formulate policies and guidelines for the city government's socialized housing and relocation projects; develop the city shelter and comprehensive land use plans, and undertake hazard, risk and vulnerability assessments (ESCAP, 2012).

Scaling-up is an issue for demand-driven, participatory approaches too, but if governments and donors would invest in such approaches and partnerships, financing would go much further than with the conventional supply-driven approaches (as per unit costs are typically lower and funds get revolved serving the intended population segments). Moreover, alongside the creation of adequate housing and infrastructure, these approaches deliver additional "social good" in the form of organized and empowered communities better able to tackle a whole host of issues. It should also be noted that when balancing affordability with population density, high-rises very quickly become too expensive, while quite high density can also be achieved with building small-size low-rise housing that mostly better fits urban poor communities.

Supporting and strengthening community processes is in the interest of city governments not only for housing and basic service provision, but also because it increases social capital, information (and with savings and outreach) also finances. People that are organized and that know and trust each other have more capacity to prepare for disaster and to recover from it and are better able to collectively express their needs and identify priorities in other words, organizing communities increases their resilience characteristics and performance.

\section{Example of an Evolving Social Enterprise Approach for Green and Affordable Building Technologies and Resilient Housing Systems}

Another smart and pro-poor approach that is gathering strength across Asia and the Pacific is trying to use market mechanisms and business principles in a sustainable way through "triple bottom line approaches" of "people, planet, and profit". Here impact investors, entrepreneurs and civil society groups (e.g. ACUMEN Fund, Ashoka, Waste Concern) are trying to deliver products and services to the "bottom of the pyramid" via "social enterprises", whose main objectives are not profit making but environmental and social development.

The example described here is an attempt to provide affordable and green building technologies and resilient housing systems to urban poor communities in the 
Philippines. The project, undertaken jointly by the Hilti Foundation, HPFPI-PACSII and ESCAP, is still in the first research phase, but its objectives strongly reflect a growing drive towards combining smart, resilient and pro-poor dimensions to urban development in Asia and the Pacific.

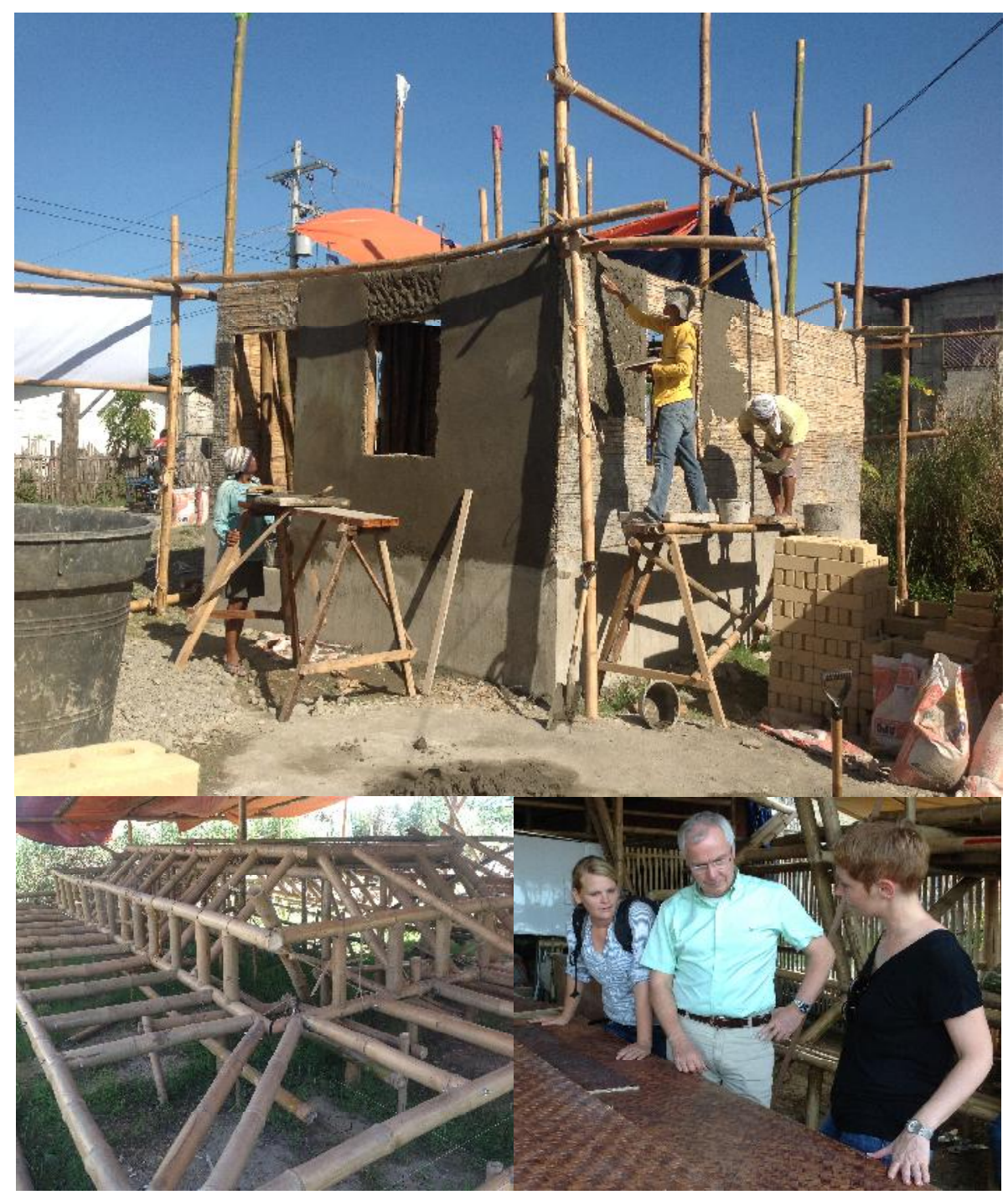

Figure 10. First Bamboo Demonstration House in Iloilo, Philippines, Bamboo Roof Structure, Pressed Bamboo Panels Source: ESCAP

As discussed above, in Asia and the Pacific, on average, around a third of all urban dwellers live in slums and in many cities more than half live in inadequate disasterprone shelter. The primary reason for this state of affairs is arguably lack of access to land. However, another main issue is the cost of quality housing. At the same 
time, the by now conventional urban construction technologies rely on steel and cement which are energy intensive and polluting technologies (the construction industry is one of the biggest emitters of GHG) that use non-renewable and increasingly expensive (and imported) raw materials.

From a technical perspective, the project therefore aims to identify building materials and technologies that are affordable, local and renewable - and which can form the basis for resilient and comfortable housing systems - designing "with the climate" and with disaster-resilience in mind. So far, the project is mainly looking into modern applications of bamboo and into combining it with the compressed interlocking earth-block technology HPFPI-PACSII is already using (see picture of ICUPN house above).

From a social perspective, embedded in the savings-based, people-centered approach of HPFPI-PACSII, communities are involved in all stages from site planning to housing design and construction to ensure the housing reflects people's priorities and is affordable. From an economic perspective, the project aims to become sustainable by running economically feasible social enterprises that produce the materials and take on construction, while also creating new supply chains for raw material and intermediary products - providing local jobs and developing new skills. The hope is also that revenues the social enterprises may make in future would support some of the overhead and "social preparation" costs for organizations such as HPFPI-PACSII to increase the capacity of NGOs and professionals to support community processes for best quality outcomes. Other related aspects, such as housing finance or holistic land use planning and site preparation are not part of the core project strategy but strengthening them by expanding HPFPI-PACSII in-house capacity or bringing in additional mechanisms and partnerships is part of the wider project strategy.

\section{CONCLUSIONS}

Strengthening resilience of urban populations and cities is not primarily about introducing specific engineering solutions, such as dams or pumping stations, though they have their place in a wider resilience framework. Building up resilience means strengthening capacities on a more basic and yet broader level that allows populations, institutions and the various urban sub-systems to cope and recover from a range of stresses and catastrophes whose timing and likelihood, severity and impact of interconnections are uncertain. A particular focus on urban poor communities is vital as they often are among the most vulnerable urban population groups that have the least capacities to cope and recover. Building resilience is therefore intimately linked to the more classical agendas of urban poverty reduction and of sustainable urban development, including addressing its structural root causes. At the same time, solutions do not have to be high-tech to be smart but the more people are included in decision-making and implementation, the more good ideas are likely to emerge. Characteristics of adaptive governance and participatory, multi stake- 
holder approaches provide a large part of the answer how to achieve resilience, so let's hope that in future both approaches will be more strongly advocated by citizens and more readily embraced by urban decision-makers.

\section{REFERENCES}

ADB (2012) Fast Facts: Vulnerable Cities - WakingUp to the Need for Urban Disaster Risk Management, <http://www.adb.org/features/fast-facts-vulnerab le-cities-waking-need-urban-disaster-risk-management $>$.

David Dodman and David Satterthwaite (2008) Institutional Capacity, Climate Change Adaptation and the Urban Poor, IDS Bulletin Volume 39 Number 4, $<$ http://www.toextremes.org/uploads/9/6/0/4/9604499/dodman_and_satterwai te $2009 . p d f>$.

David Satterthwaite (2011) Editorial: Why is community action needed for disaster risk reduction and climate change adaptation?, Environment and Develop ment, Vol 23(2), pp. 339-349

ESCAP (2010) Statistical Yearbook for Asia and the Pacific 2009

ESCAP (2011) Statistical Yearbook for Asia and the Pacific 2011

ESCAP (2012) Trends and progress in the field of environment and development: emerging and persistent issues in sustainable urban development, E/ESCAP/CED (2)/ 6, <http://www.unescap.org/esd/CED-2/documents/CED2 $6 \mathrm{E} . \mathrm{pdf}>$

IFRC (2010) World Disasters Report 2010: Focus on Urban Risk

Jo da Silva (2012) Shifting Agendas: Response to Resilience, ICE, 9th Brunel International Lecture Series, <http://www.arup.com/News/2012_05_May/ / link.aspx?_id=20FE51000643450>.

New York Times (2010), Environmental Refugees Unable to Return Home, By Joanna Kakissis, published: January 3, 2010, <http:/www.nytimes.com /2010/01/04/world/asia/04migrants.html?ref=earth>

R. Djalante (2012), Adaptive governance and resilience, Nat. Hazards Earth Syst. Sci., 12, 2923-2942, <http://www.nat-hazards-earth-syst-sci.net/12/2923 /2012/nhess-12-2923-2012.pdf $>$

Saudia Anwer (2012), Climate Refugees in Bangladesh: Understanding the migration process at the local level, <http://www.brot-fuer-diewelt.de/down loads/fachinformationen/analysis30_climate-refugees.pdf $>$.

UN Habitat (2009), State of the World's Cities Report 2008/ 2009: Harmonious Cities.

World Bank (2011), Climate Change, Disaster Risk and the Urban Poor: Cities Building Resilience for a Changing World, editor Judy L. Baker

World Economic Forum (2013), Global Risks 2013: An Initiative of the Risk Response Network, Eighth Edition, <http://www3.weforum.org/docs/WEF_ GlobalRisks Report 2013.pdf>

Bai, Xuemei and Imura, $\bar{H}$. (2000) A comparative study of urban environment in East Asia: Stage model of urban environmental evolution, International Review for Environmental Strategies, vol.1 No.1, 2000, Hayama, Japan, Insti 
tute for Global Environmental Strategies, pp. 135-158. <http://enviroscope. iges.or.jp/modules/envirolib/view.php?docid=405>. 